\title{
What the Buried Child Stands for: A Thematic Study of Sam Shepard's Buried Child
}

\author{
Feiyue Zhang ${ }^{1}$ \\ ${ }^{1}$ School of English Studies, Shanghai International Studies University, Shanghai, China \\ Correspondence: Feiyue Zhang, School of English Studies, Shanghai International Studies University, 1550 \\ Wenxiang Road, Songjiang District, Shanghai, China. E-mail: 0173100160@shisu.edu.cn
}

Received: April 8, 2020 Accepted: May 8, 2020 Online Published: May 27, 2020

doi:10.5539/ells.v10n2p75 URL: https://doi.org/10.5539/ells.v10n2p75

\begin{abstract}
As part of the family trilogy of Sam Shepard, Buried Child has been understood in that the corruption of the nuclear family has been identified as the theme of the play, and the guilt and the secret of this American family is the buried child who is regarded as the incestuous relationship between Halie and Tilden. This paper argues that the buried child is not only the illegitimate child in the family, but Dodge and every family member in the play. First, Shepard builds a multi-dimensional space in the play, in which the passage of time and the experience of characters are different, forming a chaos of narration. There are two main spaces represented in the play; the one is the living room, and the other is the backyard, and Dodge lying in the living room is equivalent to the secret child buried in the backyard. Second, Shepard uses a circular rather than linear movement in the play, which symbolizes that everything happened in the house is a closed story, and as one of elements in this circle, every family member becomes the buried child, or part of the buried child. Shepard titled the play with the buried child, using this image to depict the unchangeable influence of American family's emotional and spiritual inheritance and how it will affect future generations an even deeper mystery.
\end{abstract}

Keywords: Buried Child, cyclical structure, family connection, Sam Shepard

\section{Introduction}

The 1979 Pulitzer Prize-winning drama, Buried Child is one of Sam Shepard's most accomplished works. As part of the family trilogy of works by Sam Shepard, the corruption of the nuclear family has been identified as the theme of the play. The guilt and the secret of this American family is the buried child who is regarded as the incestuous relationship between Halie and Tilden. Critics' interpretation has been undertaken concerning Shepard's varied expressions of the suppression of the family secrect and hidden trespasses, with Family Systems Theory, postmodernism and superrealism all employed (DeRose, 1993; Opipari, 2010; Porter, 2015). Studies have found that the play gathers extensive literary allusions and myths which supplies a different functional value to that of other contemporary texts (Cadullo, 2009; Hechler, 1989), and the various use of imagery is "more as a means of intensifying a highly symbolic moment than evoking a schizophrenie reality" (DeRose, 1993, p. 143). Critics have also highlighted the aesthetics of Buried Child's cyclic structure, which is closely connected with the family's secrets and the characters' memories (Crank, 2012; Porter, 2015). However, the symbol of the buried child within the play has been examined by a comparatively few critics. The title of the play, "Buried Child" was used as a way of presenting the unchangeable influence of an American family's emotional and spiritual inheritance and its impact on future generations. This paper argues that the buried child is not only the illegitimate child in the family, but in essence, Dodge and every family member in the play. Shepard begins by building a multi-dimensional space in the play, in which the passage of time and the experience of characters are different, forming a chaotic narrative. There are two main spaces represented in the play; the living room, and the backyard, and Dodge lying in the living room is equivalent to the secret child buried in the backyard. Second, Shepard uses a circular rather than linear movement in the play. This is a symbol of everything that has happened in the house is a closed story, and as one of elements in this circle, every family member becomes the buried child, or part of the buried child. Shepard attracts the attention of the public towards how a family connection influences American people across the generations, using a cyclical structure with repetitive pattern of behaviors that become ironic metaphors of their opening appearances. 


\section{A Multi-Dimensional Space: Dodge as the Buried Child}

Buried Child is set within a multi-dimensional space. Shepard implies that Dodge located in the living room is a symbol of the child buried outside. In the play, Dodge always hides his body under the blanket, which symbolizes that he is a dying character, similar to the idea of a dead body of baby hidden underground. Like an immature child, Dodge is in his seventies; weak, powerless, coughing, dependent on pills, almost lost his ability to take care of himself in daily life. There are some hints to foreshadow Dodge's dying identity. When Halie refers to Bradley arriving to cut Dodge's hair, Dodge emphasizes that himself is "an invisible man" whose appearance is "out of mine" and even disappeared (Shepard, 2009, p. 1106). Dodge's argument with Halie in Act One saw him verbally abusing Halie, deliberately hurting her feelings by saying that Bradley was not his biological son and Dodge his own "flesh and bloods buried in the backyard" (Shepard, 2009, p. 1112). The portrayal of time and space in this play is unique as the passage of time is depicted in two layers. Firstly, time in the play reflects the classical three-unities; all the events happened in Dodge's house cover twenty-four hours. However, the crops of corn and carrot are continually harvested time on the external land within twenty-four hours, and the concept of time to different family members results in the controversial memories. Having argued with Halie about the horse racing schedule and when Tilden returns with the corns, Dodge tells Halie that "the world doesn't stop just because you're upstairs. Corn keeps growing. Rain keeps raining” (Shepard, 2009, p. 1111). Halie emphasizes that Ansel "played basketball better than anyone", while Bradley suggests that "he never played basketball" (Shepard, 2009, p. 1139). Time sequence is challenging to identify in the play, while Buried Child functions as a dramatic composition through the characters' varying perspectives. The combination of realistic and surrealistic time is used to present the relation between forgetfulness and remembering. This intensifies the sheer horror when the truth is revealed. Moreover, in terms of space, Shepard separates the house according to different isolations; Dodge is in the living room, Halie on the staircase with no landing and the buried child under the earth outside. This disparity of concepts of space enhance the distinctiveness and odd nature of the play. Halie's entrances and conversations with Dodge are always from the upstairs; she leaves in a complete black dress while arrives in a bright yellow dress. These all construct a sense of the outside and peculiarity. Dodge's efforts in preventing Halie from coming downstairs reflects the idea that each part of the house and each member of the family has its own mystery. At the end of the play, when Vince becomes the effectual patriarch rather than a stranger of the family, the characters in different dimension of space achieve a free flow and transformation of identity. Tilden makes his way upstairs with the corpse of the small child, and Halie is able to see the harvest in the backyard, which suggests that they face squarely the problems and memories that arise in their family. Shepard juxtaposes distinct perspectives concerning the same object or situation, a technique connected to the narration of fragmentation. Diverging from traditional narration, Buried Child presents time past as time present; when readers experience the text involving the characters and events across time and space, greater exertion will be required from them to ascertain what precisely the narrative is portraying.

Dodge was buried three times in the play; each time represents part of the truth of the buried child which was disclosed, as well as the process of ruining Dodge's body. Marilyn E. Hechler (1989) concluded that Shepard uses the contemporary setting and characters to "reinscribe the central actions of an ancient fertility rite" (p. 118) Shepard's use of allusion, myths and archetypes is a literary technique that connects the past and present as a continuum, with regards to the transformation of the family patriarch. The first burial custom was accomplished by the cooperation of the siblings, Tilden and Bradley. At the end of Act One, after Dodge fell asleep, Tilden "stands holding the husks over DODGE and looking down at him he gently spreads the corn husks cover the whole length of DODGE's body", and "he gathers more husk and repeats the procedure until the floor is clean of corn husks and DODGE is completely covered in them, except for his head" (Shepard, 2009, p. 1115). The action of Tilden covering Dodge's body with corn husks is not only a burial ritual of Dodge's declining patriarch in the family, but a sacrificial rite to release the sin of their family. The unfinished burial ritual of Dodge's head was passed on to the younger brother Bradley. Bradley cuts Dodge's hair with the lights dimming slowly; this denotes the end of the first burial ritual. This is also symbolic of the narrative in the Bible where Samson lost his power as a result of having his haircut without his consent. The on-stage-bury represents the younger generation taking over the older generation. Furthermore, as Halie attributes the cause of the miraculous crops in the backyard to "the sun" (Shepard, 2009, p. 1149) at the end of the play, Shepard uses a pun of sun and son to suggest that the sinful power of the buried child has flourished the barren land to produce corns and carrots. From a more sinister perspective, it is representative of the origin of evil and the incest taboo in this family which brings about the growth of Dodge's hair. The former was reaped by Tilden, and the latter was cut by Bradley. The second burial ritual occurs when Bradley covers Dodge with Shelly's fur coat at the end of Act Two: "He looks down at DODGE then drops the coat so that it lands on DODGE and covers his head" (Shepard, 2009, 
p. 1133). This burial ritual happened after Bradley's symbolic rape of Shelly, whose beauty was feeding his male-dominance in the house. This is a symbol of the further decline in Dodge's patriarchy. In addition, Shelly's coat suggests that there is an external force to facilitate the development of the authority exchange, as well as to dig for the family secret. Following Dodge's quiet death, the final on-stage-bury occurred at the end of the play as Vince lifts the blanket over his face and drops the roses on his chest. Unlike Dodge's "completely unnoticed" death (Shepard, 2009, p. 1149), Vince's violence and his similar gestures to Dodge in the final scene is a form of authoritarian announcement. Dodge, who is dodging the truth, finally dies, just as Tilden, the tiller who always returns with the crops cultivated by the corpse, tells the truth. The past has created the present, and the past is, in some way, the present. Having caused the death of the child by drowning, Dodge conducted the burial and, thus, became the person in charge of the burial of the deceased across each act.

\section{A Circular Movement: Each Family Member Representing the Buried Child}

The whole story is a circular, rather than a linear movement which reflects the characters' different perspectives, as well as a closed circle of the family. Thus, the buried child plays an active role in this circle. Laurin R. Porter (2015) used a postmodernist view to demonstrate the play's cyclic structure, said that "Buried Child's closing scene is patterned after its opening, with clearly defined parallels in dialogue, imagery and staging" (p. 108). The setting is idyllic, establishing a sense of the rural American family. In the beginning of Act Two, Shelly is willing to see a normal family like "a Norman Rockwell cover or something", and Vince says that "It's American" (Shepard, 2009, p. 1116). The representation of the ideal white middle-class family can be seen through the creation of "Dick and Jane and Spot" (Shepard, 2009, p. 1116) in Shelly's imagination. However, having described the world as being "catastrophic" (Shepard, 2009, p. 1103), Dodge shatters any perceptions of the audience. Throughout the play, water is symbolic of the origin of life and rebirth, as well as the dangers associated with death. During the first two Acts, the image of water is firstly represented by rain which soaks the characters. In the setting of the play, rain reminds the reader of the life outside, symbolizing the story of Noah in the Bible where the flood represents God's punishment of people for their sins. The continuous sound of rain is like an alarm bell which provides a warning for every sinful family member. Furthermore, the image of water calls attention to the fact that Dodge drowned the baby. In The Waste Land, there are many illusions of drowned people. Through the genesis of the poem, the drowned Phoenician sailor appears in the fourth chapter, "Death by Water", representing the real death. The suggestion is that Dodge was completely evil who will die without purification. At the end of the poem, Eliot presents three virtues "Datta, dayadhvam, damyata (Give, sympathize, control)" (Eliot, 2005, p. 1356) to depict that the rebirth of spirit will occur only after adhering to these three virtues. In Buried Child, Shepard also raises three virtues through Dodge's words: "Persistence, fortitude, and determination. Those are the three virtues. You stick with those three and you can't go wrong" (Shepard, 2009, p. 1127). Although Dodge knows the three virtues, he does not think that he will seek the redemption, alleging that "there's not a living soul behind me" (Shepard, 2009, p. 1136) and no one will hold him in the memory. In fact, the influence of Dodge's evil action has been rooted in the family. In a conversation with Dodge, Halie states that "it's just a reflection of the times" (Shepard, 2009, p. 1139) and Shepard uses the circular movement to provide a warning that there is something wrong with the American family, that the action of incest taboo and the sinful murder are evocative of a collapse in the spiritual values which identifies the American nuclear family.

Each family member in the play suffers a collective unspeakable trauma and is damaged in some way, implying that a part of the family is buried underground. Tilden buried his past crimes in New Mexico in an attempt to fix the past and find a resolution to all the trouble. Tilden's return from New Mexico reveals a new character which is both immature and demoralized. Halie used to hope that Tilden could "be the one to take responsibility", but he brought "so much trouble" (Shepard, 2009, p. 1109). In addition, Halie also lost aspects of family responsibility from being a wife and mother. By immersing herself in an illusion, Halie refers to the accomplishments and victories of the dead All-American son Ansel. This is a desire for her to create an image of heroism. Bradley is not only physically lost, but his mind is also presented to be quite evil; for example, his symbolic rape of Shelly, cutting Dodge's hair and a lack of care about his father and the other family members. Even the character of Father Dewis, who does not belong to the family directly, fails to perform the religious and moral duties delegated to him by society, which demonstrates the falling down of ethics and righteousness within America. The outsider Shelly, who doesn't "like being ignored" (Shepard, 2009, p. 1141), plays the role of a detective in the play in order to satisfy the curiosity of the audience. Whilst she investigated aspects of the house to reveal the past sins, she also tested the male characters by digging deep into their vulnerable areas: Vince's violence, Bradley's evil thoughts, Tilden's childishness and Dodge's depth of emotion. Shelly's conversations with the other family members are, in fact, a form of direct communication between the character and the reader. It is also a way of establishing the playwright's invitation to the audience to search for the biggest secret from 
within the depths of the family history. It is Shelly (the readers) that spots the fateful consequences caused by the characters who suffered the pain during the past years; when the readers establish a connected illusion of the family memories, this results in the past, the present, the play and the reality which all blends together. There is a suggestion that such events could potentially take place within an American family and nothing new would make an appearance. It is Shelly (the readers) that witnesses the corpse's burial given by Dodge in the backyard, evoking how the burial of the dead is without hope and the entire land could cease to be barren. As the only one who hadn't been fully explored, Vince would have the chance to escape from the disorientation and predicament. However, at the end of the play, the readers witness that Vince achieves a symbolic rebirth from Shelly's point of view. Vince, who is lying like Dodge on the sofa, will choose the same way to build the family. Besides Vince, through Tilden's presentation of the corpse to Halie in the final scene, Shepard suggests the representation of the vicious circle of the family's decline.

Dodge denies the family connection between him and his parents: "I never went back to my parents. Never. Never even had the urge. I was independent. Always Independent. Always found a way" (Shepard, 2009, p. 1113). Despite this, Dodge is unable to escape from the ties of the family and even shows a degree of dependency to members of this family and Shelly. According to Matthew Roudané's interview with Shepard (2002), the playwright believes that “...even if you didn't know who your father and your mother were, if you never met them, you are still intimately, inevitably, and entirely connected to who brought you into the world - through a long, long chain, regardless of whether you knew them face to face or not." (p. 68) Whilst the older generation is aligned to the importance of family identity, the younger generation are also limited to this aspect of the family. Shepard uses the allusion of the "return of the prodigal son" to strengthen the moving loop. There are two prodigal sons in the play; firstly, Tilden's return planted the seeds of evil, bringing the possibility to expose the secret of the buried child and the other is Vince, who returned in search of his family identity, but ends with disclosing the corruption and evil of his family as well as indulging in it. Tilden's return marked a turning point of the sin occurring within the family and the arrival of Vice is a reminder to the family of evil lurking in their history. When Vince returned home for the first time, he was forgotten by the whole family. Vince was anxious to reestablish a family connection and American identity; thus, he is able to know his past. However, initially, he failed as his family members began to evade and conceal the situation. When he left the house and studied his face, he identifies his family connection and his identity, whilst his face becomes another man's face, "then his face became his father's face. Same bones. Same eyes. Same nose. Same breath. And his father's face changed into his Grandfather's face..." (Shepard, 2009, p. 1148). As a site of the family's history, Vince becomes the archive of the family's both standard and deficient past. His character inherits the different identities of his ancestors; thus, he becomes a figure of both authority and evil. Shepard implies that the panic and fear inside the typical American house is in some way the embodiment of a larger illness of the whole society. However, this is not wholly accurate, and Shepard offers a possible way to obtain the absolution of the decay of the American family through Halie's words at the end of the play, that is, the "good hard rain" which "takes everything straight down deep to the roots" (Shepard, 2009, p. 1149). Only after fleeing from the pattern of the past and finding the redemption from the familial guilt will the American nuclear family break away from the vicious circle of the blood lineage.

\section{Conclusion}

With the buried child at the center of Sam Shepard's play, the focus of Buried Child is the journey of discovery. By answering who the buried child is, Shepard exposes different layers of this term from the drowned incest baby, Dodge, to every family member, foreshadowing the deep connection of American nuclear family. Alienation and Dissociation are experienced by all family members as they suffer for the sin of the family patriarch Dodge, and the denial of the reality and their actual identity dominates in the whole play. Therefore, the origin of the evil, Dodge, cannot be purified; alongside his family member, he also becomes a substitute of the buried child. The extreme dissociation not only results in their incapability to recognize their own younger generation, Vince, but involves him into the family curse. Shepard finished the exploration of the secret in the American family by showing that the corruption and dissolution of the family is from the inside, rather than the external forces. This is Shepard's first step towards introducing an opportunity to rescue the American family.

\section{References}

Cadullo, B. (2009). Literary allusions in Sam Shepard's "Buried Child". Notes on Contemporary Literature, 39(5). $\quad$ Retrieved https://link.gale.com/apps/doc/A232384012/LitRC?u=shisu\&sid=LitRC\&xid=00d463d0

Crank, J. A. (2012). Understanding Sam Shepard. The University of South Carolina Press. 
https://doi.org/10.2307/j.ctv6wgg07

DeRose, D. J. (1993). A Kind of Cavorting: Superpresence and Shepard's Family Dramas. In L. Wilcox (Ed.), Rereading Shepard: Contemporary Critical Essays on the Plays of Sam Shepard (pp. 131-149). St. Martin's Press. https://doi.org/10.1007/978-1-349-22509-5_9

Eliot, T. S. (2005). The Waste Land. In M. Ferguson, M. J. Salter \& J. Stallworthy (Eds.), The Norton Anthology of Poetry (5th ed., pp. 1344-1356). W. W. Norton \& Company.

Hechler, M. E. (1989). Past and present in American drama: The case of Eugene O'Neill and Sam Shepard (Publication No. 9012962). Doctoral dissertation, State University of New York at Stony Brook. ProQuest Dissertations and Theses Global.

Opipari, B. (2010). Shhhhhhame: Silencing the Family Secret in Sam Shepard's "Buried Child". Style, 44(1-2), $123-138$.

Porter, L. R. (2015). Modern and Postmodern Wastelands: "Long Day's Journey Into Night" and Shepard's "Buried Child". The Eugene O'Neill Review, 17(1/2), 106-119.

Roudané, M. (2002). Shepard on Shepard: an interview. In M. Roudané (Ed.), The Cambridge Companion to Sam Shepard (pp. 64-80). Cambridge University Press. https://doi.org/10.1017/CCOL0521771587.004

Shepard, S. (2009). Buried Child. In J. E. Gainor, S. B. Garner \& M. Puchner (Eds.), The Norton Anthology of Drama (vol. 2, pp. 1102-1149). W. W. Norton \& Company.

\section{Copyrights}

Copyright for this article is retained by the author, with first publication rights granted to the journal.

This is an open-access article distributed under the terms and conditions of the Creative Commons Attribution license (http://creativecommons.org/licenses/by/4.0/). 